\title{
Tracking management-related water quality alterations by phytoplankton assemblages in a tropical reservoir
}

\author{
Ren Hu • Qiuhua Li • Bo-Ping Han • \\ Luigi Naselli-Flores · Judit Padisak • \\ Nico Salmaso
}

Received: 26 May 2014/Revised: 3 June 2015 / Accepted: 9 June 2015 / Published online: 20 June 2015

(C) Springer International Publishing Switzerland 2015

\begin{abstract}
Water quality improvement and suppression of cyanobacterial blooms were planned in a eutrophic reservoir in southern China through ecological engineering measures from 2006 to 2011. This consisted in (i) a hydraulic resetting of inflows and outflows to increase the distance between inlet and outlet and the water residence time in the reservoir, and in (ii) the installation of floating frames hosting wetland vegetation to promote an alteration in phytoplankton composition. The environmental changes were therefore followed through the analysis of biotic responses in phytoplankton assemblages. Ecological engineering was effective in reducing phytoplankton total biomass, in re-establishing
\end{abstract}

Handling editor: Zhengwen Liu

R. Hu $(\bowtie) \cdot$ B.-P. Han $(\bowtie)$

Institute of Hydrobiology, Jinan University,

Guangzhou 510632, People's Republic of China

e-mail: thuren@jnu.edu.cn

B.-P. Han

e-mail: tbphan@jnu.edu.cn

Q. Li

Key Laboratory for Information System of Mountainous Area and Protection of Ecological Environment of Guizhou Province, Guizhou Normal University,

Guiyang 550001, People's Republic of China

L. Naselli-Flores

Department of Biological, Chemical and Pharmaceutical Sciences and Technologies, Section of Botany and Plant Ecology, University of Palermo, Via Archirafi 38,

90123 Palermo, Italy more diversified phytoplankton assemblages and in avoiding cyanobacterial blooms. These changes may be considered as an improvement of the reservoir water quality. However, trophic state parameters and the dynamics of dominant species were not sensitive enough in describing the environmental changes that had occurred when the eco-engineering measures were implemented. These were more effectively tracked by the dynamics followed by phytoplankton MorphoFunctional-Groups and by their classification based on Competitors, Stress tolerants and Ruderals strategies. Although providing immediate positive effects, the ecoengineering was temporally limited, highlighting the importance of constant management in the context of long-term oriented remediation techniques.

\footnotetext{
J. Padisak

Department of Limnology, University of Pannonia,

Egyetem u. 10, Veszprém 8200, Hungary

J. Padisak

MTA-PE Limnoecology Research Group, Egyetem u. 10, Veszprém 8200, Hungary

N. Salmaso

Sustainable Agro-Ecosystems and Bioresources

Department, IASMA Research and Innovation Centre, Fondazione E. Mach - Istituto Agrario di S. Michele all'Adige, Via E. Mach 1, 38010 San Michele all'Adige, Trento, Italy
} 
Keywords Phytoplankton - Morpho-functional groups $\cdot \mathrm{C}-\mathrm{S}-\mathrm{R}$-model $\cdot$ Generalized additive modelling $\cdot$ Ecological engineering $\cdot$ Reservoir

\section{Introduction}

Eutrophication leads to an excessive increase of algal biomass often accompanied by a series of negative effects, such as unpleasant taste, odour, dominance of toxin-producing cyanobacteria, oxygen depletion and drinking water treatment problems (Anderson, et al., 2002; Paerl et al., 2011a). Many techniques for ecological restoration and water quality improvement have been developed to avoid phytoplankton blooms in lakes (Xu et al., 1999; Reddy \& Char, 2006). These attempts were aimed at a direct reduction of phytoplankton biomass or addressed towards the alteration of the assemblage composition through the management of the hydrological patterns (Jugnia et al., 2004; Paerl et al., 2011b). The adopted methods include (i) hydrological operations, such as flushing, alteration of vertical mixing and/or diversion of nutrient input, and (ii) biological measures, such as food-chain management and interaction with macrophytes (Rodríguez Gallego et al., 2004; Jeppesen et al., 2005b; Verdonschot et al., 2013).

Eutrophication management in the tropics should fully recognize the differences in the climate and hydrodynamics of water bodies when mitigation measures are compared to those adopted in the temperate zones (Lewis, 2000; Jeppesen et al., 2005a). Biomanipulation, for instance, is not effective in tropical regions because of the weaker top-down control of phytoplankton due to the smaller size of zooplankton and the higher predation exerted on it by continuously reproducing omnivorous fish (Meerhoff et al., 2007; Kosten et al., 2009). Conversely, macrophyte planting has been considered a major strategy to restore lakes, especially when internal loads represent a major contribution to the total nutrients (Gulati et al., 2008; Moss et al., 2013). Macrophytes not only compete for nutrients and light, but also provide a refuge for zooplankton, promote sedimentation of suspended matter and prevent its resuspension. Moreover, they have been suggested to excrete allelopathic substances inhibiting phytoplankton growth (Gross et al., 2007). However, the effectiveness of such benefits on water clarity in tropical reservoirs appears to be smaller than in temperate zones (Kosten et al., 2009). The wide water-level fluctuations experienced by tropical and sub-tropical reservoirs restrict the use of macrophytes as a measure against eutrophication. Conversely, regulation of inflow and outflow regimes in reservoirs was demonstrated to influence water retention time, stratification, vertical mixing and sedimentation as well as distribution of suspended solids, with important effects on phytoplankton assemblages (Padisák et al., 1999; Naselli-Flores, 2003, 2014; Jugnia et al., 2004; Rigosi \& Rueda, 2012).

Evaluating the effectiveness of any specific restoration is not easy. Commonly used water quality indicators, such as total phosphorus (TP), total nitrogen (TN) as well as Secchi disk (SD) transparency, may vary during time (Fee, 1976). Even chlorophyll $a$ (Chl- $a$ ), a widely regarded surrogate of phytoplankton biomass, is not reliable because of the different flushing rates in lakes and reservoirs, and because its dependence on the composition and physiological state of phytoplankton (Geider, 1987). On the other hand, changes in species composition and relative abundance of the biota provide information about changes in the ecological state of a given ecosystem. Phytoplankton composition and its response to changed environmental conditions can therefore act as an indicator of the ecological conditions of aquatic ecosystems (Huszar \& Caraco, 1998).

Instead of individual species, phytoplankton morphological and functional groups have often been used to infer modification in ecological conditions (Izaguirre et al., 2012; Segura et al., 2013), especially in relation to physical and chemical variables (Abonyi et al., 2012; Mihaljević et al., 2013). Salmaso \& Padisák (2007) developed a Morpho-FunctionalGroups (MFG) classification of freshwater phytoplankton based on morphological, physiological and taxonomical features. This classification system was used to track the environmental changes in tropical reservoirs in southern China, providing consistent results with the Reynolds' Functional Groups (FG; Reynolds et al., 2002; Padisák et al., 2009; Hu et al., 2013). By grouping phytoplankton according to their morphology, three main $\mathrm{C}-\mathrm{S}-\mathrm{R}$-survival strategies can be identified. Originally described by Grime (1977) for terrestrial plants, the C-S-R-model well describes the adaptive morphological features of 
phytoplankton in relation to nutrient and light availability (Reynolds, 1997). These survival strategies reflect the intensities of stress (resource availability) and disturbance (duration of the stress and physical disturbances), and their assessment can facilitate the interpretation of the environmental scenario to which algal cells are subjected in their planktonic life (Reynolds, 2006; Naselli-Flores \& Barone, 2011).

Therefore, both the variations of dominant phytoplankton morphologies (C-S-R-survival strategies) and the ecological classification into MFG were adopted to evaluate the water quality improvement by ecological engineering project in a sub-tropical reservoir. We hypothesized that the ecological measures should have an important effect on the assemblage structure and therefore on the selection of different functional attributes and strategies of phytoplankton species. To test this idea, a study was carried out on a 7-year phytoplankton dataset to evaluate the water quality improvement achieved through the adopted ecological engineering measures (EEM). These achievements were evaluated taking into account both classical trophic status proxies (such as nutrient concentrations, biomass of cyanobacteria and water transparency) and the variation in the structure of phytoplankton assemblages.

\section{Materials and methods}

Study site

Dajingshan reservoir is located in Zhuhai city, southern China $\left(22^{\circ} 17^{\prime} 42.5^{\prime \prime} \mathrm{N}, 113^{\circ} 33^{\prime} 04.4^{\prime \prime} \mathrm{E}\right)$. The reservoir is one of the main sources of drinking water for the cities of Zhuhai and Macao. It is a medium-sized reservoir with very small drainage basin; its main limnological characteristics are shown in Table 1 . The water body, receiving high TP and TN loads from the downstream of Pearl River, shows an eutrophic state (Li \& Han, 2007). Since the reservoir's ongoing eutrophication was not taken in account by managers and hydrological engineers, the inlet and outlet were designed to cross the dam closely (Fig. 1). Consequently, a waterway shortcut was automatically formed keeping stagnant a large part of the pelagic zone. The reservoir does not have any natural inflow, and most of the stored water is pumped from the
Table 1 Main characteristics of Dajingshan reservoir

\begin{tabular}{ll}
\hline & Dajingshan reservoir \\
\hline Year of impoundment & 1,979 \\
Volume $\left(10^{7} \mathrm{~m}^{3}\right)$ & 1.053 \\
Mean water level $(\mathrm{m})$ & 20.4 \\
Watershed area $\left(\mathrm{km}^{2}\right)$ & 5.95 \\
Maximum depth $(\mathrm{m})$ & 13.5 \\
Mean depth $(\mathrm{m})$ & 8.6 \\
Annual average precipitation $(\mathrm{mm})$ & 1,991 \\
Annual average water supply $\left(10^{7} \mathrm{~m}^{3}\right)$ & 4.287 \\
Mean WRT (d) & 90 \\
Level oscillation $\left(\mathrm{m}^{2}\right)$ & 6.2 \\
Mean inflow rate $\left(\mathrm{m}^{3} \mathrm{~s}^{-1}\right)$ & 6.5 \\
Mean outflow rate $\left(\mathrm{m}^{3} \mathrm{~s}^{-1}\right)$ & 7.69 \\
Thermal stratification & January-December \\
\hline
\end{tabular}

WRT water retention time

downstream part of the Pearl River. An additional water source is represented by direct precipitation during the monsoonal summer (from early May to late September). The water-level fluctuates seasonally, showing its lowest values in early summer and the highest in early winter.

Ecological engineering measures (EEM)

EEM included (1) the redirection of inflows and outflows by a channel in front of the dam (400 m long and $200 \mathrm{~m}$ wide), with the installation of filtering curtains $\left(1.12 \times 10^{5} \mathrm{~m}^{2}\right.$ and $15 \mathrm{~m}$ deep $)$ delimiting the channel, and (2) installation of bamboo framed floating beds $\left(2.6 \times 10^{4} \mathrm{~m}^{2}\right)$ with macrophytes (mostly Paspalum vaginatum Swartz, Cynodon dactylon (L.) Persoon and Zoysia japonica Steudel) covering the area outside the channel and in front of the outlets (Fig. 1). After the inflow divergence, the distance between inlet and outlet extended from less than 200 to more than $800 \mathrm{~m}$. Nearly $30 \%$ of the stagnant part of the lake was influenced by the divergence. In 2010, a partial renovation of all the macrophytes was done. However, the bamboo-floating frame, without further investment to be maintained, started decaying in early 2010. Altogether, the EEM was implemented to redirect the flows, to position floating artificial mats and to apply vertical curtains (for more details see Li, 2008). 
Fig. 1 Sampling sites in Dajingshan reservoir. The lake is located $4 \mathrm{~km} \mathrm{NW}$ of Zhuhai city, South China. Arrows indicate the inflow and outflow point and direction

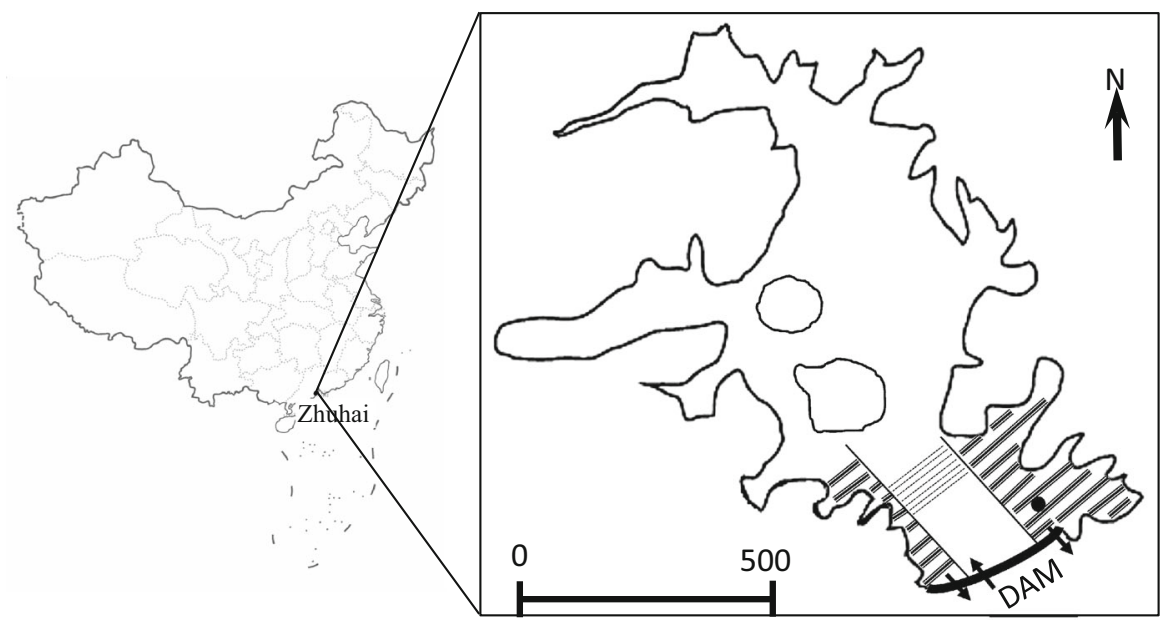

Sampling and measurements

Phytoplankton was collected biweekly/monthly in 2005 (24 samples) and 2006 (19 samples), and monthly (12 samples) from 2007 to 2011. Samples for phytoplankton analyses, Chl- $a$ and chemical analyses were collected close to the outflow of the reservoir (Fig. 1). Taking into account the low water transparency (generally $<1.5 \mathrm{~m}$ ), samples were collected $0.5 \mathrm{~m}$ below the water surface. This layer was assumed representative of the surface, illuminated epilimnetic layer (cf. Fig. 2).
Temperature $\left({ }^{\circ} \mathrm{C}\right)$
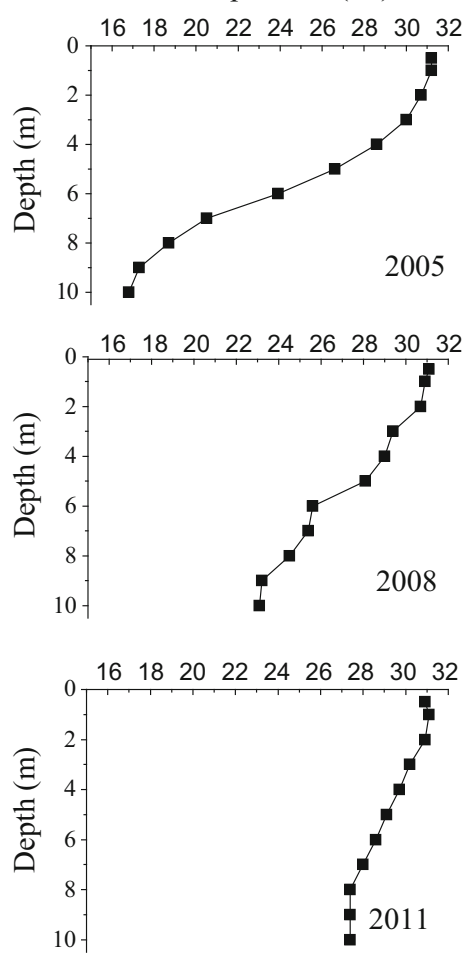

Temperature $\left({ }^{\circ} \mathrm{C}\right)$
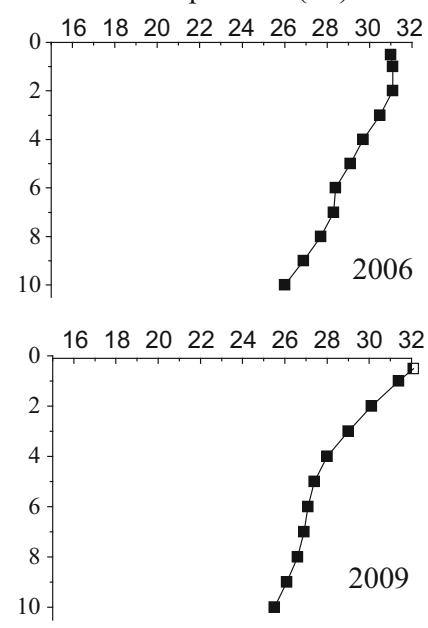

Temperature $\left({ }^{\circ} \mathrm{C}\right)$
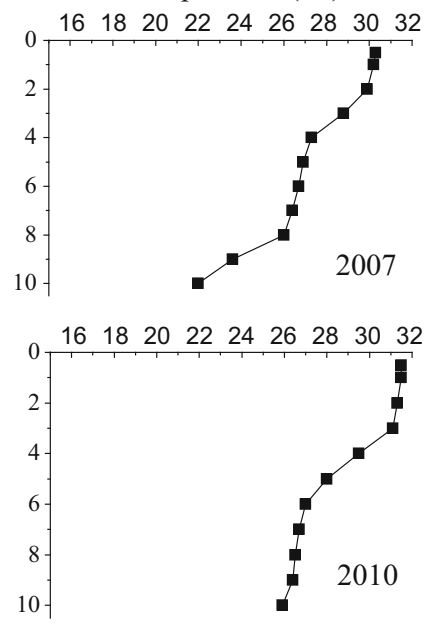

Fig. 2 Vertical profiles of temperature in August from 2005 to 2011 in Dajingshan reservoir 
Water transparency was measured using a SD, and the euphotic zone $\left(Z_{\mathrm{eu}}\right)$ was estimated by multiplying water transparency by 2.7 (Cole, 1994). Water temperature, dissolved oxygen, electrical conductivity, salinity and $\mathrm{pH}$ were measured using a portable multiparameter probe (YSI 6600V, Yellow Spring Instruments, Ohio, USA).

Chl- $a$ was measured spectrophotometrically by filtering $500 \mathrm{ml}$ of water through a $0.45-\mu \mathrm{m}$ cellulose acetate filters and extracting the pigment with acetone after repeated freezing and thawing (Lorenzen, 1967; Lin et al., 2005).

Soluble reactive phosphorus (SRP), nitrite $\left(\mathrm{NO}_{2}-\right.$ $\mathrm{N})$, nitrates $\left(\mathrm{NO}_{3}-\mathrm{N}\right)$, ammonium $\left(\mathrm{NH}_{4}-\mathrm{N}\right)$, $\mathrm{TN}$ and TP were analysed according to APHA (2012).

Hydrological data (precipitation, water level, volume, inflow and outflow) were provided by the Zhuhai Water Group Company. For multivariate analysis, the averaged inflow over a 2-week period prior to each sampling was considered.

For phytoplankton counting, one-litre of water preserved with $5 \%$ formalin and $1 \%$ Lugol's iodine solution was allowed to settle in a graduated flask. After 48-72 h, the supernatant was syphoned off with a 2-mm diameter hose and the residual $(35 \mathrm{ml})$ was collected for microscopic counting. At least 400 algal units $(\geq 2 \mu \mathrm{m})$ were counted in each sample using a Sedgewick-Rafter chamber under a BX51 Olympus microscope at $400 \times$ magnification (APHA, 2012; Hu et al., 2013). Three replicates for each sample were counted and phytoplankton cells or colonies were measured to estimate biovolume. The biomass was calculated from biovolume estimates according to Hillebrand et al. (1999). Phytoplankton was identified at the lowest taxonomical rank possible, and species were grouped into MFG following Salmaso \& Padisák (2007). Taxonomical grouping was made at levels of genus, order and class. The definition of genera and major groups of eukaryotic algae is coherent with the recent systematics described by Krienitz (2009) and Guiry \& Guiry (2013).

\section{Data analysis}

To allow comparison of the data collected in 2005 and 2006 with the successive period, the analyses were carried out on a matrix of monthly averages (12 observations per year) for both environmental and biological data.
Considering that many variables did not show a linear or monotonic response along the temporal gradient, the fluctuations of a few, selected environmental variables and cyanobacteria were modelled using Generalized Additive Models (GAMs). GAMs used in this work were based on non-linear regressions and smoothing splines. The GAM can identify if the smoother is a straight line, and test the validity of linear regression models to the data (Zuur et al., 2009). The types of models are described by the effective degrees of freedom (edf); the higher is the edf, the more non-linear is the smoothing spline.

The dynamics of phytoplankton assemblages were analysed by Nonmetric Multidimensional Scaling (NMDS) applied to Bray \& Curtis' dissimilarity matrices computed on biovolume values (Salmaso, 1996). NMDS configurations were obtained for the taxonomical classifications of genera, orders, classes and MFG. Rare species found in less than 3 occasions and biovolumes $<500 \mathrm{~mm}^{3} \mathrm{~m}^{-3}$ over the whole study period were not included in the analyses. Before the computation of NMDS, the data were transformed by double square root to reduce the weight of the most abundant taxa (Clarke \& Green, 1988). NMDS was started with different random starting coordinates and the solution with the lowest "stress" (Kruskal \& Wish, 1978) was selected after 25 trials (Oksanen et al., 2013). The final solutions were rotated so that the variances of site scores were maximized on the first axes. In the NMDS configurations, the ordination of taxa and MFG was obtained computing biovolume weighted averages of site scores (Oksanen et al., 2013). The maximum correlation of the single variables with the samples in the NMDS configuration was analysed with vector fitting. The direction and length of the fitted vectors indicate the direction of most rapid change in the environmental variable and the strength of the correlation between the environmental variable and the configuration, respectively. The significance of the single vectors was estimated computing 1000 random permutations of the data (Oksanen et al., 2013).

The morphological properties of the dominant taxa were plotted in a XY graph month by month. This method allows distributing the taxa inside a triangle whose corners identify the three main theoretical CS-R-survival strategies adopted by phytoplankton. The points scattered on these graphs were unified by a line to observe the seasonal trajectories followed by 
phytoplankton in a particular year and to compare them from year to year (Naselli-Flores \& Barone, 2007). By plotting the monthly morphological descriptors $\left(m s v^{-1}\right.$ against $s v^{-1}$, where $m, s$ and $v$ are the maximum linear dimension, surface area and volume of the vegetative units, respectively), it is possible to depict the successional trends followed by phytoplankton in relation to nutrient and light availability.

Statistical analyses were carried out with the vegan (Oksanen et al., 2013) packages in $\mathrm{R}$ ( $\mathrm{R}$ Development Core Team, 2013).

\section{Results}

Temporal dynamics of physical and chemical variables

In the first 5 years (2005-2009), annual average inflows varied between ca. $60 \times 10^{3}$ and $90 \times 10^{3} \mathrm{~m}^{3}$ day $^{-1}$. Elevated mean annual inflows (2010: $105 \times 10^{3}$ and 2011: $110 \times 10^{3} \mathrm{~m}^{3} \mathrm{day}^{-1}$ ) were recorded in the last 2 years. Water levels were positively correlated with the inflow values $\left(n=84, r^{2}=0.47, \quad P<0.01\right)$. Surface water temperature exceeded $25^{\circ} \mathrm{C}$ from May to September. The lowest temperatures were recorded in January and February $\left(15^{\circ} \mathrm{C}\right)$. In 2008 and 2009, winter temperatures showed higher minimum values $\left(18-21^{\circ} \mathrm{C}\right)$. The vertical temperature profiles showed a weaker stratification after the installation of the water channel in 2006 (Fig. 2).

The seasonal TP concentrations showed peaks $>40 \mu \mathrm{g} \mathrm{l}^{-1}$ at the end of the dry season (March or April). Lower concentrations $\left(<20 \mu \mathrm{g}^{-1}\right)$ were observed in the middle of the flood season (July to August) when precipitation was at its maximum. Mean annual values of TP were higher in 2005-2006 $\left(35 \mu \mathrm{g} \mathrm{l}^{-1}\right)$ and 2010-2011 $\left(31 \mu \mathrm{g}^{-1}\right)$ than in 2007-2009 (24 $\left.\mu \mathrm{g} \mathrm{l}^{-1}\right)$.

Annual TN ranged between 0.4 and $2.56 \mathrm{mg} \mathrm{l}^{-1}$, showing a seasonal pattern with lower and higher concentrations in the rainy (mean $0.83 \mathrm{mg} \mathrm{l}^{-1}$ ) and dry seasons (mean $1.36 \mathrm{mg}^{-1}$ ), respectively. The pattern corresponds to the lower inflow from river to the lake in the rainy seasons. Neither TN nor dissolved inorganic nitrogen differed significantly before and after the EEM was adopted.
There were two peaks of water transparency each year, one occurring in the summer and the other at about the end of winter. Transparency and euphotic depth values ranged between 0.5 and $1.8 \mathrm{~m}$, and 1.4 and $4.9 \mathrm{~m}$, respectively. The annual mean transparency was lower in 2005-2007 and 2011 (0.8-0.9 m; $Z_{\mathrm{eu}}$ between 2.2 and $2.4 \mathrm{~m}$ ), and higher in 2008-2010 (1.1-1.2 m; $Z_{\text {eu }}$ between 3.0 and $\left.3.2 \mathrm{~m}\right)$.

Chl- $a$ variability and phytoplankton composition

Chl- $a$ concentrations varied widely (3-63 $\mu \mathrm{g} \mathrm{l}^{-1}$ ). Peaks occurred usually at the end of the dry seasons (from March to May) and, occasionally, at the beginning of the dry season (October to December). At the beginning (2005-2007) and during the last year (2011), the annual mean concentrations of Chl- $a$ were between 32 and $34 \mu \mathrm{g}^{-1}$. The mean concentrations in 2008-2010 were between 21 and $27 \mu \mathrm{g} \mathrm{l}^{-1}$.

Altogether, 114 phytoplankton species belonging to 93 genera, 29 orders and 10 classes were identified during the study period. Cyanobacteria were the most abundant group before and at the starting period of the ecological engineering (Fig. 3d). During its maximum development (2005-2008, and 2011), this group was mainly dominated by Microcystis spp. Towards the end of 2008, the dominance shifted to filamentous cyanobacterial species, namely Pseudanabaena limnetica (Lemmermann) Komárek followed by Limnothrix sp. and Planktolyngbya sp. These three taxa persisted in the water body throughout the whole ecological engineering period. During the first 3 years (2005-2007), cyanobacteria reached high biovolumes, with seasonal peaks between $15 \times 10^{3}$ and $30 \times$ $10^{3} \mathrm{~mm}^{3} \mathrm{~m}^{-3}$ during the late winter and early spring months. In the successive years, and particularly between 2009 and 2010, their biomass showed a drastic decrease, and then recovered in 2011 to the first year (2005) levels (Fig. 3d). Annual mean values of cyanobacterial biovolumes between 2005 and 2008 ranged from 1,000 to $6,000 \mathrm{~mm}^{3} \mathrm{~m}^{-3}$ (ca. $30-80 \%$ of total biovolumes), whereas the corresponding values in 2009 and 2010 were 335 and $36 \mathrm{~mm}^{3} \mathrm{~m}^{-3}$, respectively (ca. 5-20\%). The importance of cyanobacteria in the phytoplankton assemblage and their influence on the light regime were exemplified by the significant relationships with Chl- $a\left(r^{2}=0.1\right.$, $P<0.01)$ and SD transparency $\left(r^{2}=0.13, P<0.01\right)$. 

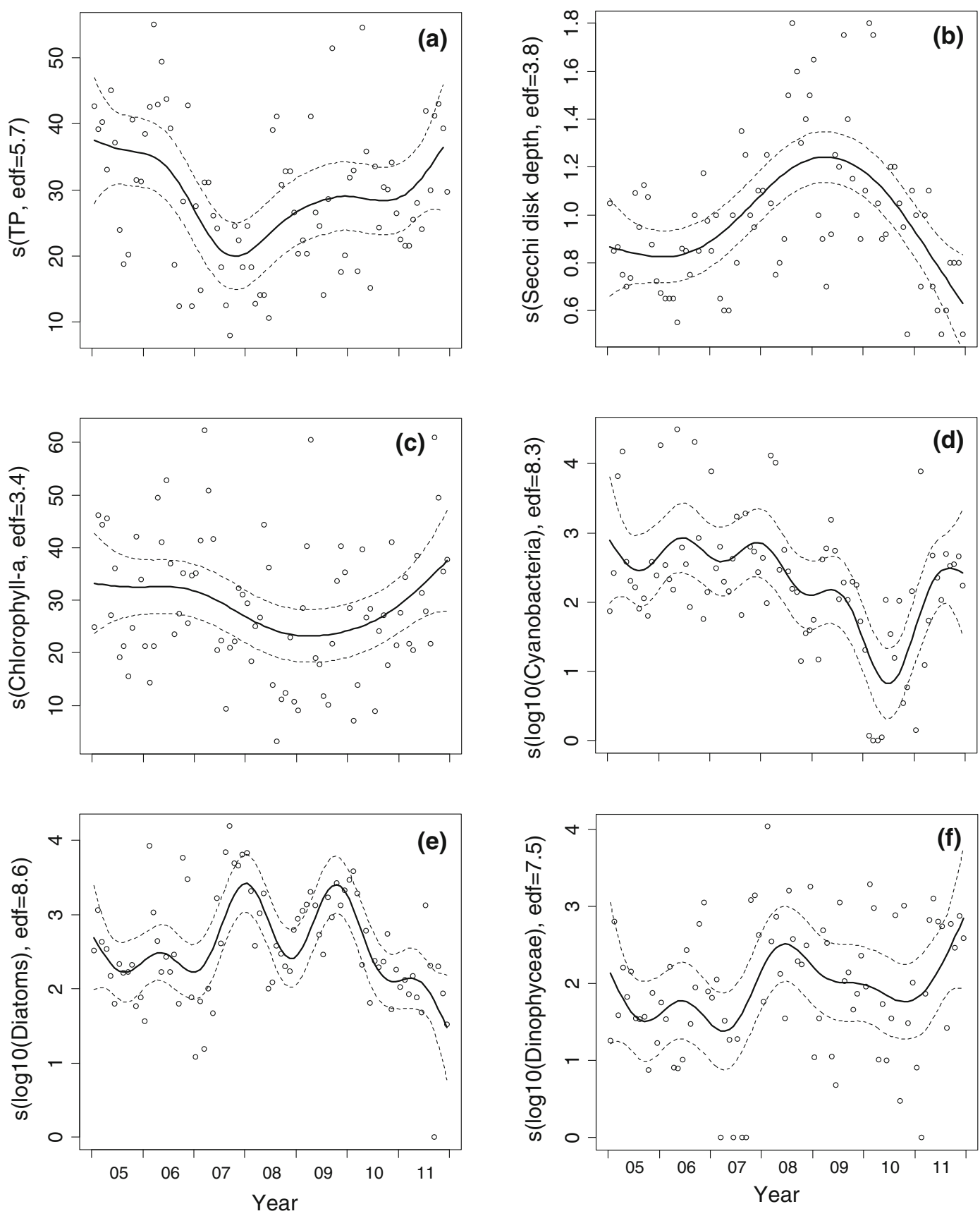

Fig. 3 GAM models with a TP $\left(\mu \mathrm{g} 1^{-1}\right)$, b Secch disk depth (m), c Chllorophyll- $a\left(\mu \mathrm{g}^{-1}\right)$, d cyanobacteria, e diatoms and f dinoflagellates $\left(\mathrm{mm}^{3} \mathrm{~m}^{-3}\right)$. The solid line is the smoother

Except cyanobacteria and diatoms, the other phytoplankton groups had low density. Diatoms were almost equally abundant in all the observed years. Centric diatoms were principally represented by $C y$ clotella meneghiniana Kützing and Aulacoseira

(s) and the dotted lines $95 \%$ confidence bands. Approximate significance of smooth terms: a, b, d, e $P<0.01$, c $P=0.052$, f $P=0.11$. Ecological engineering measures began in 2006

granulata (Ehrenberg) Simonsen. Pennate diatoms belonged mostly to genera Synedra and Achnanthidium. They showed an increasing biomass in the middle of the investigation period (Fig. 3e). The lowest annual average densities $\left(<250 \mathrm{~mm}^{3} \mathrm{~m}^{-3}\right)$ of diatoms were 
recorded at the beginning and at the end of the study (2005 and 2011). Dinophyceae were the most abundant algal class after the cyanobacteria and diatoms. This group showed a slight increase after the first part of the investigation (Fig. 3f). The dominant species included small sized taxa (Peridinium spp.) followed by larger species as Ceratium hirundinella (O.F.Müller) Dujardin and Glenodinium pulvisculus (Ehrenberg) Stein. The remaining algal classes did not exceed annual biovolume averages of $300 \mathrm{~mm}^{3} \mathrm{~m}^{-3}$.

\section{GAM models}

The application of GAM models allowed confirming and describing the long-term dynamics of the environmental and phytoplankton data. It also helped to identify the most probable shape of the relationships, providing a way to test statistically the smoothers. The GAM computations clearly confirmed the significant $(P<0.01)$ decrease of TP soon after the setting of EEM (Fig. 3a). This decrease was paralleled by a significant increase $(P<0.01)$ in the transparency values just after the improvement period and before the decaying of the bamboo framed floating bed (Fig. 3 b). Nevertheless, the two models suggested a shift of ca. 1 year in the increase of SD compared to the decrease of TP. Although at the border of significance, Chl- $a$ showed a decline in the middle of the research study ( $P=0.052$; Fig. 3c). Throughout the study period (2005-2011), SD was significantly related to Chl- $a$ (Fig. $4 \mathrm{a} ; r^{2}=0.47, P<0.01$ ). The effect of the algal biomass on water transparency was more apparent considering the annual averages (Fig. $4 \mathrm{~b} ; r^{2}=0.87, P<0.01$ ).
The variation of cyanobacterial biomass showed a delayed response to the restoration project. GAM models confirmed an abrupt and significant $(P<0.01)$ decline of cyanobacteria particularly after 2008, and a tendency to establish again the previous biovolume values during the very last period (Fig. 3d). Conversely, the analysis showed a clear tendency $(P<0.01)$ of diatoms to increase in the central period (Fig. 3e), and a less strong (and not significant, $P=0.11)$ tendency of dinoflagellates to increase after 2007 (Fig. 3f).

The GAM analyses did not show any U-shaped pattern in the 7-year temporal dynamics of the inflow data, but the U-shape was common for the most other variables. Instead, inflows appeared to be characterized by a linear tendency to increase (edf $=1$, $P<0.01)$. Excluding some positive significant relationships between the water level $(P<0.01)$, the water transparency $(P<0.01)$ and concentration of nitrates $(P<0.01)$ nd a marginal negative relationship between water level and cyanobacteria $(P=0.1)$, the variables used to describe hydrology did not show significant correlations with the other environmental and biotic variables.

Overall, the above results allow separating the study period into three succession stages: (1) starting stage, approximately from 2005 to 2006; (2) improvement stage, approximately from 2007 to 2009; and (3) decay stage, from 2010 to 2011 . The massive decay of bamboo frames at the end of 2010 resulted in a sharp increase of TP, cyanobacteria, and Chl- $a$, followed by a decrease of SD. Diatoms and dinoflagellates increased with the restoration programme and declined when the bamboo frames decayed.
Fig. 4 Linear regression of Secchi disk depth (SD) vs. chlorophyll- $a(\mathrm{Chl}-a)$. a Raw data, $\mathbf{b}$ annual averages. Data were $\log _{10}$ transformed
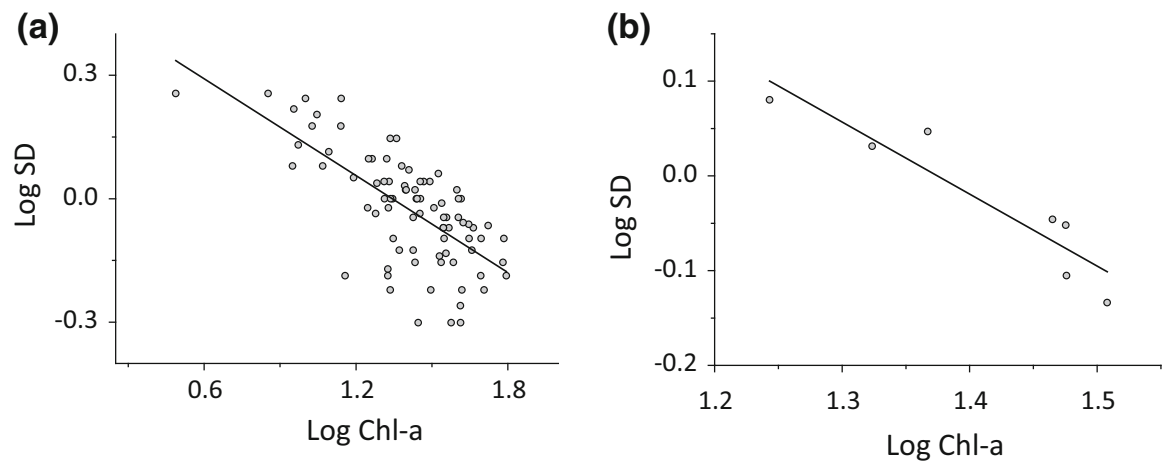
C-S-R-survival strategies of phytoplankton

From 2005 to 2007, a continuous shift in dominance between the R-strategists (filamentous cyanobacteria) and the S-strategists (Microcystis spp.) occurred in the reservoir (Fig. 5). Particularly, the large majority of species recorded in 2006 showed morphological features typical of S-strategists, such as the large mucilaginous colonies (e.g. Microcystis spp.) and the large sized unicellular flagellates (e.g. Peridinium spp.), which were dominant for more than 4 months. When the improvement appeared (2008-2009), a new successional pattern of phytoplankton that included $\mathrm{C}$-strategists as an additional component (e.g. $\mathrm{Cy}$ clotella meneghiniana) was recorded. C-strategists were generally followed by R-strategists (e.g. Aulacoseira granulata) and by S-strategists (Peridinium sp.). The trajectories depicted by plotting the morphological properties of the dominant algae include all the $\mathrm{C}-\mathrm{S}-\mathrm{R}$-survival strategies graph and are more rounded as the result of the alternation of the different strategists during these 2 years. The trajectory in 2010 showed a "star" shape with only three rays from one centre. This period was characterized by an almost exclusive presence of C-strategists (Cyclotella meneghiniana for 9 months). Although with a different peak in August (due to a greater development of Peridinium volzii Lemmerman), a sharp return back to a "hooked" shape (as in 2005-2007) occurred in 2011.
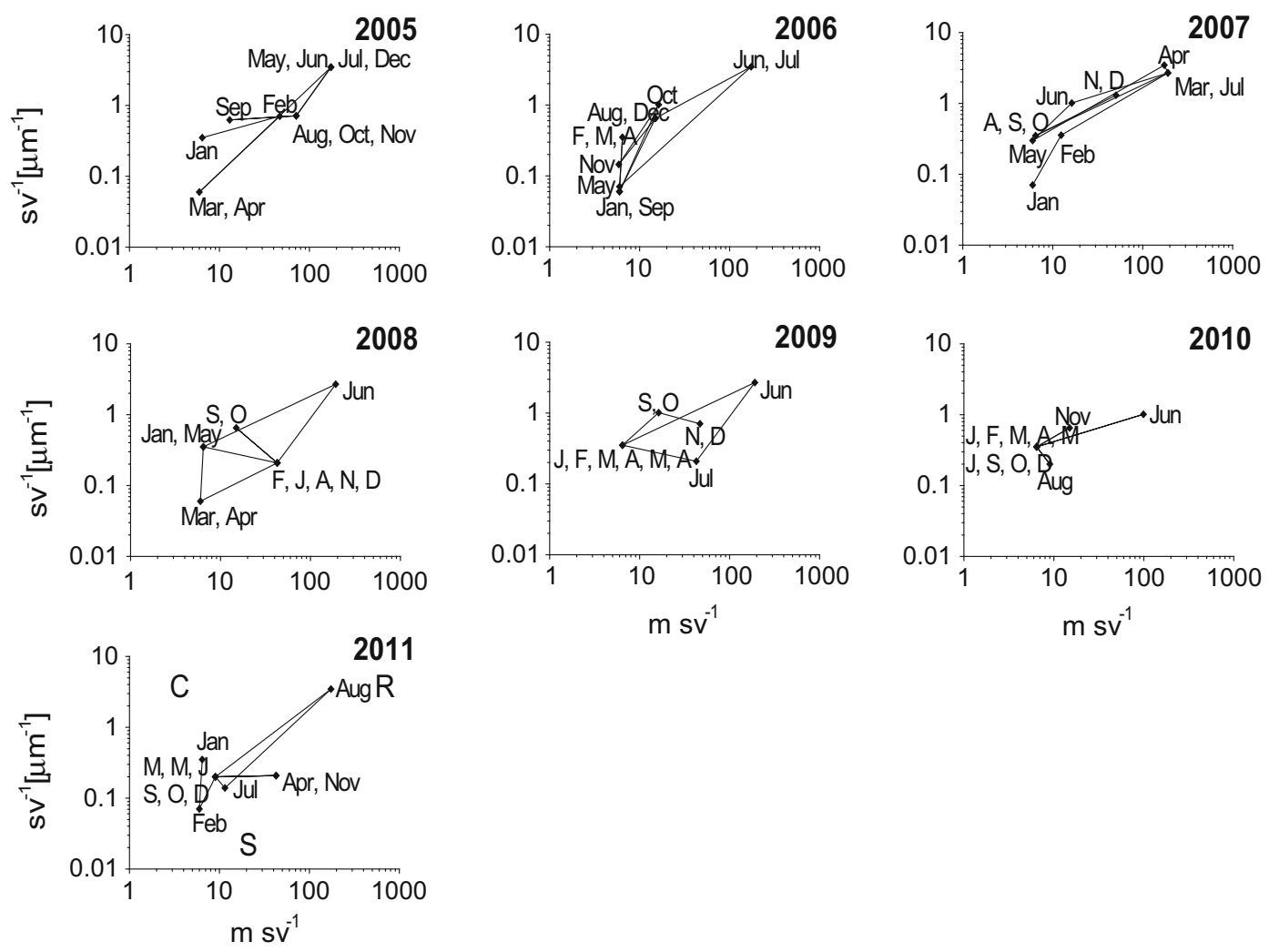

Fig. 5 Plot of the C-S-R-survival strategies showing the seasonal trajectories traced by dominant species of phytoplankton in the period 2005-2011. Ecological engineering measures in the lake begun in 2006. The approximate location of the C-, $\mathrm{S}$-, and R-strategists are reported in the last graph. $\mathrm{sv}^{-1}$ and $m s v^{-1}$ represent dimension and shape gradients, respectively (Reynolds, 2006). The species selected for the C-S-Rclassification include those dominant in the single months, i.e. Cyclotella meneghiniana, Synedra ulna, Synedra sp.,
Pseudanabaena limnetica, Planktolyngbya sp., Limnothrix sp., Planktothrix sp., Cylindrospermopsis sp., Staurastrum gracile, Staurastrum natator, Microcystis wesenbergii, Microcystis aeruginosa, Raphidiopsis sp., Aulacoseira granulata, Peridinium sp., Peridinium volzii, Ceratium hirundinella, Cosmarium sp., Achnanthes sp., Surirella sp., Monactinus simplex, Trachelomonas sp., Discostella stelligera, Coelastrum microporum, Coscinodiscus lacustris, Pleodorina sp., Gomphonema sp., Stigonema sp 
Seasonal phytoplankton dynamics

All phytoplankton species were classified into 25 morpho-functional groups. The frequency of occurrence of MFG varied in the three management stages (starting, improvement and decaying). The frequencies of $2 \mathrm{~b}$ (small dinophytes) and $6 \mathrm{a}$ (large centrics) increased when improvement occurred.

The ordination of phytoplankton community based on the single genera and MFG is reported in Fig. 6
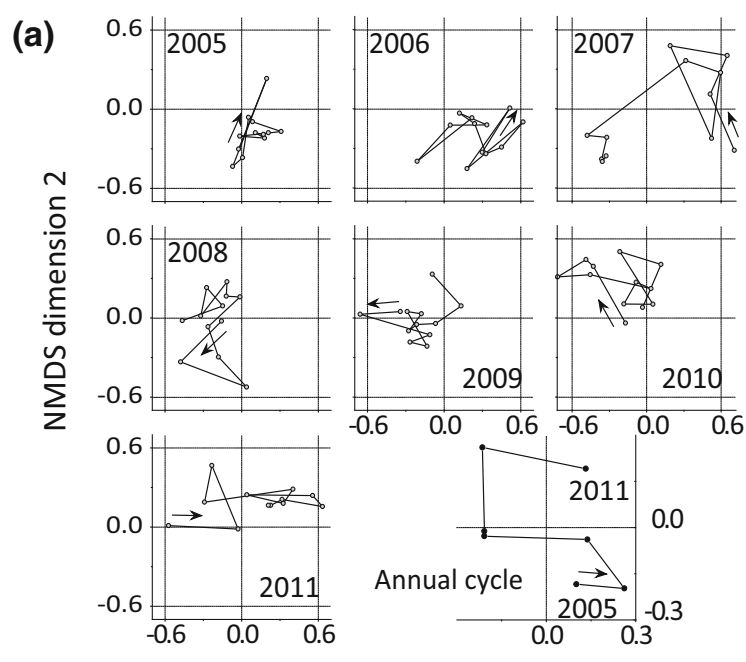

NMDSdii1

(b)

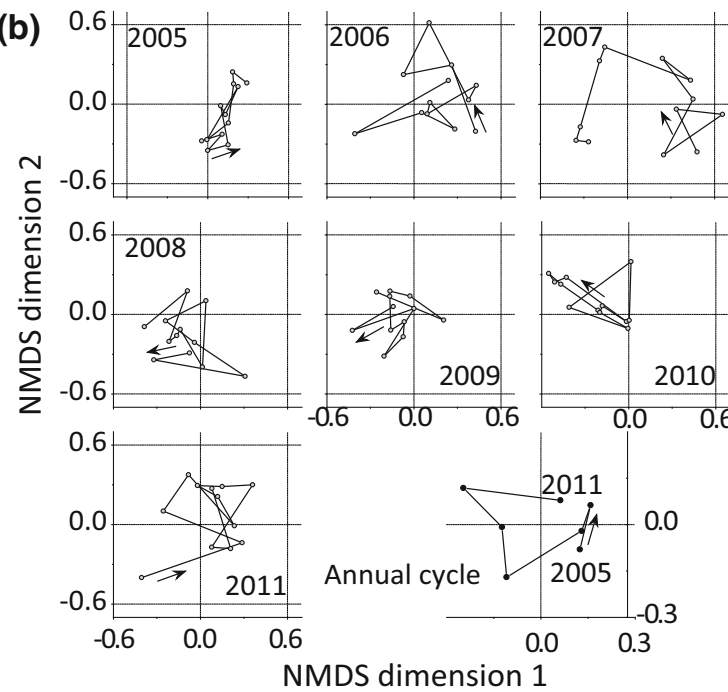

Fig. 6 NMDS ordinations of monthly phytoplankton samples based on a phytoplankton genera and b MFG. In both panels, the last graphs reports the centroids (monthly averages) of the coordinates computed for each year. Ecological engineering measures began in 2006
(Oksanen et al., 2013). To better understand the seasonal development of phytoplankton, the configuration was further split and plotted separately for each year. The last graphs in Figs. 6a, b show the centroids of the years, whose position was determined by computing the annual averages of the coordinates along the $\mathrm{x}$ and $\mathrm{y}$ axes. The seasonal dynamics in the single years did not show a comparable cyclic pattern. However, the dynamics of the yearly configurations appeared in accordance with the three stages of the study period. According to the analyses based on phytoplankton genera (Fig. 6a), the yearly configurations were condensed and located in the lower quadrants in 2005 and 2006. Since 2007, the yearly configuration showed a tendency to move to the left and upper quadrants. The yearly configuration returned to the right quadrant in 2011.

Compared with phytoplankton genera, similar patterns in the NMDS configurations were demonstrated also using MFG (Fig. 6b). The change of the seasonal configuration started in 2006 with a more sparse distribution of the samples. The change in the MFG was apparent from 2008 to 2010, when the monthly samples gathered in the left side of the quadrant. As in the case of the genera-based analysis, the yearly configuration moved towards the original position in 2011.

The two configurations obtained with the genera and MFG exhibited comparable patterns. This can be shown by comparing the relationships between the coordinates of the first two axes in the different NMDS configurations. In the genera-based NMDS and in the MFG-based NMDS, the couples of axes 1 , and the couples of axes 2 were highly correlated $(P<0.01)$. This was also true $(P<0.01)$ comparing the first axes of these configurations with those based on orders and classes. Conversely, the second axes of the configurations obtained with genera, orders and classes, showed low correlations, being only at the border of significance (orders, $P=0.051$ ) or not significant (classes, $P>0.1$ ). Interestingly, the second axes by MFG and classes were highly correlated $(P<0.01)$.

The differentiation of the seasonal phytoplankton configurations in the three management stages is further sharpened in Figs. 7a, b, which illustrate the NMDS ordinations based on MFG of the whole set of monthly samples (2005-2011). The vector fitting analyses have been included in the NMDS. In 2005 and 2011, the annual developments of monthly 
(a)

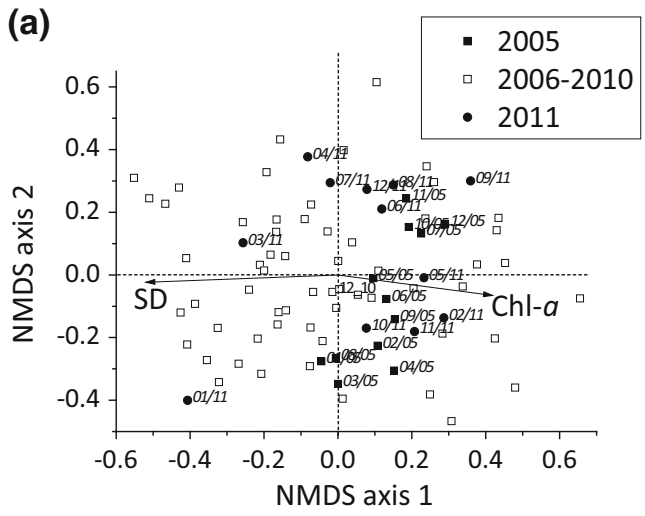

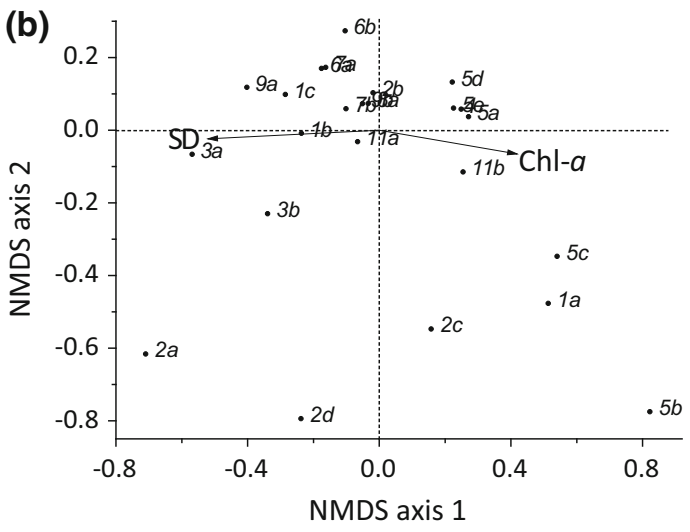

Fig. 7 NMDS of a phytoplankton samples and $\mathbf{b}$ MFG with vector fitting

sampled phytoplankton were located in the right quadrants, while the corresponding annual development of phytoplankton in 2006-2010 was spread throughout the four quadrants (Fig. 7a). The gradient of samples along the first axis was significantly $(P<0.01)$; positively linked to the long-term variations of Chl- $a$ and negatively to SD. Although less strongly $(P<0.05)$, other two variables, $\mathrm{NO}_{3}-\mathrm{N}$ and water level, showed a link with the configuration of samples. Genera-based configurations gave a similar vector fitting, but with a less significant link with $\mathrm{NO}_{3}$ $\mathrm{N}$ and water level (figure not shown).

In Fig. 7b, the MFG shift is clearly evident over the three EEM stages. All the cyanobacteria MFG (5a-5e) were located in the right quadrants. The other MFG in this part of the configuration also included $11 \mathrm{~b}$ (Chlorococcales and gelatinous colonies), 1a (large chrysophytes) and 2c (small euglenophytes). On the other hand, with the increase of SD and decrease of Chl- $a$ (left quadrants), cyanobacteria were replaced by flagellated species belonging to $3 \mathrm{a}-3 \mathrm{~b}$ (Phytomonadina), 2a (small chrysophytes), 2d (cryptophytes), $1 \mathrm{~b}$ (large dinophytes) and 1c (large euglenophytes), as well as small unicelullar desmids (9a).

\section{Discussion}

The strong connection between eutrophication and dominance of cyanobacteria was widely demonstrated in many lake types and latitudes (Smith \& Schindler, 2009; Paerl et al., 2011a). In eutrophic and hypertrophic environments, cyanobacteria can outcompete other algal groups, because of their better nutrient assimilation and storage capacity (Paerl et al., 2001), floating ability and buoyancy control (Reynolds et al., 1987), light harvesting efficiency (Antenucci et al., 2005) and production of allelopathic compounds (Sukenik et al., 2002).

Before EEM were set in the studied reservoir, cyanobacteria were the dominant phytoplankton group, contributing most to total phytoplankton biomass and determining low water transparency values. Cyanobacterial abundance decreased from 2007 to 2010 after the applied EEM contributed to decrease TP concentrations and to reduce underwater light intensity. As already observed by Havens et al. (1998) in a shallow sub-tropical lake, phytoplankton biomass, especially that of high-light adapted, bloomforming taxa such as the S-strategist Microcystis spp. strongly decreased when water transparency decreased due to the shading effect of floating beds. The latter effect occurred earlier than the decrease in TP. However, cyanobacteria decreased continuously, although weakly, during the early second stage of the engineering when TP concentrations reached their minimum. This resilience to recover after a decrease in nutrient availability is commonly observed in aquatic environments (Ibelings et al., 2007). In particular, the persistence of cyanobacteria can be due to the large inocula of Microcystis (Cirés et al., 2013) already present in the studied reservoirs when the treatment started.

The decrease of Microcystis biomass during the EEM period was accompanied by a replacement of species in favour of a more diversified group, mostly 
including small and large flagellates, and small unicelullar desmids. The relapse of freshwater ecosystems in their former trophic state and phytoplankton structure when initial nutrient levels are re-established is a well-known phenomenon (Jeppesen et al., 1991; James et al., 1994; Goldyn et al., 2003). Accordingly, Microcystis suddenly started increasing again, along with TP concentrations, when the floating beds were removed.

The deviation of the inflow to the central part of the reservoir enhanced the water fluxes in the pelagic zone. By channelizing the inflowing water and eroding the stratification, the horizontal circulation of water masses contributed to reduction of cyanobacterial dominance. Modelling studies in the Villerest Reservoir (River Loire, France) also showed that the outflow created a current at the depth of the sluice that broke the vertical stratification and influenced lake circulation and Microcystis development (Bonnet \& Poulin, 2002). More in general, flushing has been shown to suppress cyanobacteria blooms (Padisák et al., 1999; Verspagen et al., 2006; Tolotti et al., 2010), favouring the dominance of diatoms and green algae (Brookes et al., 2003). In the zone covered by the floating bamboo structures, the stratification was further weakened by the lower values of surface water temperature as a consequence of the coverage with the beds of macrophytes.

The increased SD values, observed in the period when EEM were effective, were consequent upon the reduction of phytoplankton and mineral particles. In general, the relationship between SD and Chl- $a$ is stronger in deep lakes than in reservoirs, because the reservoirs contain more inorganic suspended solids from rivers (Salmaso \& Zignin, 2010). In the Dajingshan reservoir the strong relationship between SD and Chl- $a$ could mean that the majority of inorganic particles settled to the sediments or attached to the curtains before reaching the outlet.

A previous study from southern China (Hu et al., 2013) and other studies from different environments (Abonyi et al., 2014; Petar et al., 2014) consistently showed that MFG were able to provide an ecological classification of phytoplankton fully comparable with that obtained with FGs (Reynolds et al., 2002). The present study showed a strong concordance between the MFG and genera-based ordinations, and an increasing discordance between the genera-based configurations and those based on higher taxonomical units (i.e. orders and classes). This result suggests that when evaluating the effects of different ecological measures on the phytoplankton structure, the classifications based on taxonomical units higher than genera have poorer performance than those based on functional traits (e.g. MFG).

C-S-R-survival strategies and MFG are based on a different number of FG (3 and 31, respectively), highlighting different characteristics and bio-complexity levels of functional diversity. The C-S-Rmodel is a tool to distinguish the limiting resources in the water body from nutrient to light through ordination of dominant species according to their life strategies (Reynolds, 2006 and references therein). Accordingly, despite the low number of groups, it allowed to distinguish a clear pattern of change between basic life strategies during the management operations.

The floating beds used in the present project provided two main functions by (i) consuming nutrients and (ii) attenuating the amount of light available to phytoplankton, and contributed to decrease the dominance of both S-strategists and R-strategists in the period 2008-2009. Actually, the lower number of S-strategists species observed in 2008 and 2009 suggests that nutrients were no longer stored in big sized individuals or colonies, and coincides with the lower TP values measured in the study period. In the same way, the fewer R-strategists recorded in this period were the result of lower disturbance to the aquatic environment likely caused by water divergence and filtering curtains. The seasonal succession of phytoplankton during the functioning of EEM presented a pattern closer to the theoretical one where C-strategists exploit resources at an early stage of the seasonal succession and, by decreasing nutrients and light availability, drive the compositional change of phytoplankton assemblages (cf. Reynolds, 2006).

Seasonal variations of phytoplankton assemblages are very ample and typical in temperate regions and often characterized by a high degree of predictability from 1 year to the other (Sommer et al., 2012). The interannual seasonal recurrence of environmental conditions in temperate lakes was shown to cause strong cyclical changes in phytoplankton assemblages (George et al., 2000; Salmaso \& Padisák, 2007). Conversely, the seasonal environmental differentiation is not so apparent in tropical and sub-tropical zones. The seasonality of phytoplankton assemblages 
is also less clear than in temperate regions. In the present study, hydrology was strongly manipulated, interfering with precipitations and inflow, which are considered as important potential environmental driver in low-latitude lakes (Melack, 1979; De Senerpont Domis et al., 2013). Seasonal phytoplankton dynamics in Dajingshan reservoir, described by NMDS analysis with phytoplankton genera and MFG, did not follow seasonal patterns as demonstrated, using the same statistical techniques, in lakes Garda and Stechlin (Salmaso \& Padisák, 2007). These results further confirm the basic differences in the effects of different climatic regimes on phytoplankton in temperate and tropical regions. NMDS configurations clearly showed that the EEM strongly modified phytoplankton seasonality at the level of phytoplankton genera and MFG, through changing the dominance of species mostly belonging to cyanobacteria, diatoms and dinoflagellates.

The EEM adopted in the Dajingshan reservoir represent an integration of biological and hydrological management methods. They included hydraulic divergence by deflectors, nutrients removal and underwater light attenuation by the floating beds of macrophytes. In general, these measures also favour the sedimentation of particulate $\mathrm{P}$ in the inlet part of the reservoir, the transferring of nutrients into higher plants and partially on the surface of the curtains. Concentrations of $\mathrm{TP}$ in Dajingshan reservoir, varying from 40 to $71 \mu \mathrm{g} \mathrm{l}^{-1}$ before the setting of the EEM, were below $30-35 \mu \mathrm{g}^{-1}$ in 2008. These values are considered a threshold discriminating mesotrophic and eutrophic states according to the OECD criteria (Vollenweider $\&$ Kerekes, 1982). Furthermore, as stated by Downing et al. (2001), the risk of cyanobacteria dominance ( $>50 \%$ of total biovolume) is only $0-10 \%$ for concentrations of TP between 0 and $30 \mu \mathrm{g} 1^{-1}$, rising abruptly to about $40 \%$ between 30 and $70 \mu \mathrm{g} 1^{-1}$, and reaching $80 \%$ at TP values around $100 \mu \mathrm{g} \mathrm{l^{-1 }}$.

Although Dajingshan reservoir has been subjected to high external nutrient loading from the River Pearl, the internal loading from sediments is also very high (see Lin et al., 2006). It was demonstrated that only a significant and prolonged reduction in external loads can eventually reduce internal nutrient recycling in lakes (Burger et al., 2008), inducing a persistent decline of cyanobacteria as shown, for example, in Lake Balaton (Istvánovics et al., 2007; Hajnal \& Padisák, 2008).

\section{Conclusions}

The hydraulic resetting of inflows and outflows, which allowed water residence time to increase, and the installation of the floating frames hosting macrophytes contributed to ameliorate the water quality in the studied reservoir. Owing to the significant decrease of phytoplankton biomass (especially cyanobacteria) as described by the reduction of TP concentrations, the EEM modified underwater light climate and increased water transparency. At the phytoplankton species level, these changes, although not influencing significantly total phytoplankton biomass, caused a strong rearrangement in the functional properties of assemblages promoted by the increased light availability. This was effectively revealed by the seasonal dynamics of both morpho-functional groups and strategic groups (C-S-R-survival strategies). After the interruption of EEM, a boost of cyanobacteria biomass and a relapse to the earlier status quickly occurred. Overall, this investigation showed how EEM specifically adapted to the conditions of tropical reservoirs was able to strongly condition not only water quality, but also the overall functional structure of the whole phytoplankton community. From the other side, our data indicate that, though EEM might result in immediate positive responses, they require a constant management.

Acknowledgements Support by grants from Chinese NSF (No. 31070416) and the Fundamental Research Funds for the Central Universities (No. 21613105) and the grant from Guangdong Province for leading talent scientists to Dr Henri Dumont is appreciated. Thanks for the Zhuhai water group company to provide the hydraulic data for the Dajingshan reservoir.

\section{References}

Abonyi, A., M. Leitão, A. Lançon \& J. Padisák, 2012. Phytoplankton functional groups as indicators of human impacts along the River Loire (France). Hydrobiologia 698: 233-249.

Abonyi, A., M. Laitão, I. Stankovic, G. Borics, G. Várbíró \& J. Padisák, 2014. A large river (River Loire, France) survey to compare phytoplankton functional approaches: do they display river zones in similar ways? Ecological Indicators 46: 11-22.

American Public Health Association, 2012. Standard Methods for the Examination of Water and Wastewater, 22nd edn. American Water Works Association and Water Pollution Control Federation, Washington, DC, USA: 1360 pp. 
Anderson, D. M., P. M. Glibert \& J. M. Burkholder, 2002. Harmful algal blooms and eutrophication: nutrient sources, composition, and consequences. Estuaries 25: 704-726.

Antenucci, J. A., A. N. Ghadouani, M. I. Burford \& J. O. Romero, 2005. The long-term effect of artificial destratification on phytoplankton species composition in a subtropical reservoir. Freshwater Biology 50: 1081-1093.

Bonnet, M. P. \& M. Poulin, 2002. Numerical modelling of the planktonic succession in a nutrient-rich reservoir: environmental and physiological factors leading to Microcystis aeruginosa dominance. Ecological Modelling 156: 93-112.

Brookes, J. D., R. H. Regel \& G. G. Ganf, 2003. Changes in the photo-chemistry of Microcystis aeruginosa in response to light and mixing. New Phytologist 158: 151-164.

Burger, D. F., D. P. Hamilton \& C. A. Pilditch, 2008. Modelling the relative importance of internal and external nutrient loads on water column nutrient concentrations and phytoplankton biomass in a shallow polymictic lake. Ecological Modelling 211: 411-423.

Cirés, S., L. Wormer, R. Agha \& A. Quesada, 2013. Overwintering populations of Anabaena, Aphanizomenon and $\mathrm{Mi}$ crocystis as potential inocula for summer blooms. Journal of Plankton Research 35(6): 1254-1266.

Clarke, K. R. \& R. H. Green, 1988. Statistical design and analysis for a "biological effects" study. Marine Ecology Progress Series 46: 213-226.

Cole, G. A., 1994. Textbook of Limnology. Waveland Press, Long Grove, IL: 421.

De Senerpont Domis, L. N., J. J. Elser, A. S. Gsell, V. L. M. Huszar, B. W. Ibelings, E. Jeppesen, S. Kosten, W. M. Mooij, F. Roland, U. Sommer, E. Van Donk, M. Winder \& M. Lürling, 2013. Plankton dynamics under different climatic conditions in space and time. Freshwater Biology 58: 463-482.

Downing, J. A., S. B. Watson \& E. McCauley, 2001. Predicting cyanobacteria dominance in lakes. Canadian Journal of Fisheries and Aquatic Sciences 58: 1905-1908.

Fee, E. J., 1976. The vertical and seasonal distribution of chlorophyll in lakes of the Experimental Lakes Area, northwestern Ontario: implications for primary production estimates. Limnology and Oceanography 21(6): 767-783.

Geider, R. J., 1987. Light and temperature dependence of the carbon to chlorophyll a ratio in microalgae and cyanobacteria: implications for physiology and growth of phytoplankton. New Phytologist 106(1): 1-34.

George, D. G., J. F. Talling \& E. Rigg, 2000. Factors influencing the temporal coherence of five lakes in the English Lake District. Freshwater Biology 43: 449-461.

Goldyn, R., T. Joniak, K. Kowalczewska-Madura \& A. Kozak, 2003. Trophic state of a lowland reservoir during 10 years after restoration. Hydrobiologia 506-509: 759-765.

Grime, J. P., 1977. Evidence for the existence of three primary strategies in plants and its relevance to ecological and evolutionary theory. American Naturalist 111: 1169-1194.

Gross, E. M., S. Hilt, P. Lombardo \& G. Mulderij, 2007. Searching for allelopathic effects of submerged macrophytes on phytoplankton - state of the art and open questions. Hydrobiologia 584: 77-88.

Guiry, M. D. \& G. M. Guiry, 2013. AlgaeBase. World-wide Electronic Publication. National University of Ireland,
Galway. http://www.algaebase.org; searched on 20 November 2013.

Gulati, R. D., L. M. Dionisio Pires \& E. Van Donk, 2008. Lake restoration studies: failures, bottlenecks and prospects of new ecotechnological measures. Limnologica - Ecology and Management of Inland Waters 38: 233-247.

Hajnal, É. \& J. Padisák, 2008. Analysis of long-term ecological status of Lake Balaton based on the ALMOBAL phytoplankton database. Hydrobiologia 599: 227-237.

Havens, K. E., E. J. Phlips, M. F. Cichra \& B. L. Li, 1998. Light availability as a possible regulator of cyanobacteria species composition in a shallow subtropical lake. Freshwater Biology 39: 547-556.

Hillebrand, H., C. D. Dürselen, D. Kirschtel, U. Pollingher \& T. Zohary, 1999. Biovolume calculation for pelagic and benthic microalgae. Journal of Phycology 35: 403-424.

Hu, R., B. Han \& L. Naselli-Flores, 2013. Comparing biological classifications of freshwater phytoplankton: a case study from South China. Hydrobiologia 701: 219-233.

Huszar, V. L. M. \& N. F. Caraco, 1998. The relationship between phytoplankton composition and physical-chemical variables: a comparison of taxonomic and morphological-functional descriptors in six temperate lakes. Freshwater Biology 40: 679-696.

Ibelings, B. W., R. Portielje, H. E. R. R. Lammens, R. Noordhuis, M. S. van den Berg, W. Joosse \& M. L. Meijer, 2007. Resilience of alternative stable states during the recovery of shallow lakes from eutrophication: Lake Veluwe as a case study. Ecosystems 10: 4-16.

Istvánovics, V., A. Clement, L. Somlyódy, A. Specziár, L. G. Tóth \& J. Padisák, 2007. Updating water quality targets for shallow Lake Balaton (Hungary), recovering from eutrophication. Hydrobiologia 581: 305-318.

Izaguirre, I., L. Allende, R. Escaray, J. Bustingorry, G. Pérez \& G. Tell, 2012. Comparison of morpho-functional phytoplankton classifications in human-impacted shallow lakes with different stable states. Hydrobiologia 698: 203-216.

James, R. T., K. O’Dell \& V. H. Smith, 1994. Water quality trends in Lake Tohopekaliga, Florida, USA: responses to watershed management. Journal of the American Water Resources Association 30: 531-546.

Jeppesen, E., P. Kristensen, J. P. Jensen, M. Søndergaard, E. Mortensen \& T. Lauridsen, 1991. Recovery resilience following a reduction in external phosphorus loading of shallow, eutrophic Danish lakes: duration, regulating factors and methods for overcoming resilience. Memorie dell' Istituto Italiano di Idrobiologia 48: 127-148.

Jeppesen, E., M. Søndergaard, N. Mazzeo, M. Meerhoff, C. Branco, V. Huszar \& F. Scasso, 2005a. Lake restoration and biomanipulation in temperate lakes: relevance for subtropical and tropical lakes. In Reddy, M. V. (ed.), Restoration and Management of Tropical Eutrophic Lakes. CRC Press, Boca Raton: 341-359.

Jeppesen, E., M. Søndergaard, J. P. Jensen, K. E. Havens, O. Anneville, L. Carvalho, M. F. Coveney, R. Deneke, M. T. Dokulil, B. Foy, D. Gerdeaux, S. E. Hampton, S. Hilt, K. Kangur, J. Köhler, E. H. H. R. Lammens, T. L. Lauridsen, M. Manca, M. R. Miracle, B. Moss, P. Nõges, G. Persson, G. Phillips, R. Portielje, S. Romo, C. L. Schelske, D. Straile, I. Tatrai, E. Willén \& M. Winder, 2005b. Lake responses to reduced nutrient loading - an analysis of 
contemporary long-term data from 35 case studies. Freshwater Biology 50: 1747-1771.

Jugnia, L. B., D. Debroas, J. C. Romagoux \& J. Devaux, 2004. Initial results of remediation activities to restore hypereutrophic Villerest Reservoir (Roanne, France). Lakes and Reservoirs: Research and Management 9: 109-117.

Kosten, S., G. Lacerot, E. Jeppesen, D. Da Motta Marques, E. H. van Nes, N. Mazzeo \& M. Scheffer, 2009. Effects of submerged vegetation on water clarity across climates. Ecosystems 12: 1117-1129.

Krienitz, L., 2009. Algae. In Likens, Gene. E. (ed.), Encyclopedia of Inland Waters, Vol. 1. Academic Press, Oxford: 103-113.

Kruskal, J. B. \& M. Wish, 1978. Multidimensional Scaling. Sage Publications, Beverly Hills and London: 93.

Lewis, W. M., 2000. Basis for the protection and management of tropical lakes. Lakes and Reservoirs: Research and Management 5: 35-48.

Li, Q. H., 2008. The Effects of Ecotechnological Engineering on Improving Water Quality and the Dynamical Characteristics of Phytoplankton in Dajingshan Reservoir [D]. PhD thesis. Jinan University, Guangzhou: 182 pp.

Li, Q. H. \& B. P. Han, 2007. Structure and dynamics of phytoplankton community based CCA analysis in a pumped storage reservoir. Acta Ecologia Sinica 27: 2355-2364.

Lin, S. J., L. J. He, P. S. Huang \& B. P. Han, 2005. Comparison and improvement on the extraction method for chlorophyll a in phytoplankton. Chinese Journal of Ecologic Science 24: 9-11.

Lin, Z. W., T. Yin, Z. Tan, B. P. Han, Y. C. Feng, B. X. Tan \& X. M. Zheng, 2006. Sediment deposition and its trapping nitrogen and phosphorus in Dajingshan reservoir. Journal of Anhui Agricultural Sciences 34: 3441-3443.

Lorenzen, C. J., 1967. Determination of chlorophyll and pheopigments: spectrophotometric equations. Limnology and Oceanography 12: 343-346.

Meerhoff, M., J. M. Clemente, F. T. De Mello, C. Iglesias, A. R. Pedersen \& E. Jeppesen, 2007. Can warm climate-related structure of littoral predator assemblies weaken the clear water state in shallow lakes? Global Change Biology 13: $1888-1897$.

Melack, J. M., 1979. Temporal variability of phytoplankton in tropical lakes. Oecologia 44: 1-7.

Mihaljević, M., D. Špoljarić, F. Stević \& T. Žuna Pfeiffer, 2013. Assessment of flood-induced changes of phytoplankton along a river-floodplain system using the morpho-functional approach. Environmental Monitoring and Assessment 621: 1-19.

Moss, B., E. Jeppesen, M. Søndergaard, T. L. Lauridsen \& Z. Liu, 2013. Nitrogen, macrophytes, shallow lakes and nutrient limitation: resolution of a current controversy? Hydrobiologia 710: 3-21.

Naselli-Flores, L., 2003. Man-made lakes in Mediterranean semi-arid climate: the strange case of Dr Deep Lake and $\mathrm{Mr}$ Shallow Lake. Hydrobiologia 506-509: 13-21.

Naselli-Flores, L., 2014. Morphological analysis of phytoplankton as a tool to assess ecological state of aquatic ecosystems. The case of Lake Arancio, Sicily, Italy. Inland Waters 4: 15-26.

Naselli-Flores, L. \& R. Barone, 2007. Pluriannual morphological variability of phytoplankton in a highly productive
Mediterranean reservoir (Lake Arancio, Southwestern Sicily). Hydrobiologia 578: 87-95.

Naselli-Flores, L. \& R. Barone, 2011. Invited review-fight on plankton! Or, phytoplankton shape and size as adaptive tools to get ahead in the struggle for life. Cryptogamie, Algologie 32: 157-204.

Oksanen, J., F. G. Blanchet, R. Kindt, P. Legendre, P. R. Minchin, R. B. O'Hara, G. L. Simpson, P. Solymos, M. H. H. Stevens \& H. Wagner, 2013. Vegan: Community Ecology Package. R Package Version 2.0-10. http://cran.rproject.org/web/packages/vegan/.

Padisák, J., J. Köhler \& S. Hoeg, 1999. Effect of changing flushing rates on development of late summer Aphanizomenon and Microcystis populations in a shallow lake, Müggelsee, Berlin, Germany. In Tundisi, J. G. \& M. Straskraba (eds), Theoretical Reservoir Ecology. Backhuys Publishers, Leiden: 411-424.

Padisák, J., L. Crossetti \& L. Naselli-Flores, 2009. Use and misuse in the application of the phytoplankton functional classification: a critical review with updates. Hydrobiologia 621: 1-19.

Paerl, H. W., R. S. Fulton, P. H. Moisander \& J. Dyble, 2001. Harmful freshwater algal blooms, with an emphasis on cyanobacteria. Scientific World Journal 1: 76-113.

Paerl, H. W., N. S. Hall \& E. S. Calandrino, 2011a. Controlling harmful cyanobacterial blooms in a world experiencing anthropogenic and climatic-induced change. Science of the Total Environment 409: 1739-1745.

Paerl, H. W., H. Xu, M. J. McCarthy, G. Zhu, B. Qin, Y. Li \& W. S. Gardner, 2011b. Controlling harmful cyanobacterial blooms in a hyper-eutrophic lake (Lake Taihu, China): the need for a dual nutrient (N \& P) management strategy. Water Research 45: 1973-1983.

Petar, Ž., G. U. Marija, K. B. Koraljka, P. Anđelka \& J. Padisák, 2014. Morpho-functional classifications of phytoplankton assemblages of two deep karstic lakes. Hydrobiologia 740(1): 147-166.

R Core Team, 2013. R: A Language and Environment for Statistical Computing. R Foundation for Statistical Computing, Vienna, Austria. http://www.R-project.org/.

Reddy, M. S. \& N. Char, 2006. Management of lakes in India. Lakes \& Reservoirs: Research \& Management 11: 227-237.

Reynolds, C. S., 1997. Vegetation Processes in the Pelagic: A Model for Ecosystem Theory. Ecology Institute, Oldendorf/Luhe: 371.

Reynolds, C. S. 2006. The Ecology of Phytoplankton (Ecology, Biodiversity and Conservation). Cambridge University Press, Cambridge: 535 pp.

Reynolds, C. S., R. L. Oliver \& A. E. Walsby, 1987. Cyanobacterial dominance: the role of buoyancy regulation in dynamic lake environments. New Zealand Journal of Marine and Freshwater Research 21: 379-390.

Reynolds, C. S., V. Huszar, C. Kruk, L. Naselli-Flores \& S. Melo, 2002. Towards a functional classification of the freshwater phytoplankton. Journal of Plankton Research 24: 417-428.

Rigosi, A. \& F. J. Rueda, 2012. Hydraulic control of short-term successional changes in the phytoplankton assemblage in stratified reservoirs. Ecological Engineering 44: 216-226.

Rodríguez Gallego, L. R., N. Mazzeo, J. Gorga, M. Meerhoff, J. Clemente, C. Kruk, F. Scasso, G. Lacerot, J. García \& F. 
Quintans, 2004. The effects of an artificial wetland dominated by free-floating plants on the restoration of a subtropical, hypertrophic lake. Lakes \& Reservoirs: Research \& Management 9: 203-215.

Salmaso, N., 1996. Seasonal variation in the composition and rate of change of the phytoplankton community in a deep subalpine lake (Lake Garda, Northern Italy). An application of nonmetric multidimensional scaling and cluster analysis. Hydrobiologia 337: 49-68.

Salmaso, N. \& J. Padisák, 2007. Morpho-Functional Groups and phytoplankton development in two deep lakes (Lake Garda, Italy and Lake Stechlin, Germany). Hydrobiologia 578: 97-112.

Salmaso, N. \& A. Zignin, 2010. At the extreme of physical gradients: phytoplankton in highly flushed, large rivers. Hydrobiologia 639: 21-36.

Segura, A. M., C. Kruk, D. Calliari \& H. Fort, 2013. Use of a morphology-based functional approach to model phytoplankton community succession in a shallow subtropical lake. Freshwater Biology 58: 504-512.

Smith, V. H. \& D. W. Schindler, 2009. Eutrophication science: where do we go from here? Trends in Ecology \& Evolution 24(4): 201-207.

Sommer, U., R. Adrian, L. De Senerpont Domis, J. J. Elser, U. Gaedke, B. Ibelings, E. Jeppesen, M. Lürling, J. C. Molinero, W. M. Mooij, E. van Donk \& M. Winder, 2012. Beyond the Plankton Ecology Group (PEG) Model: mechanisms driving plankton succession. Annual Review of Ecology, Evolution, and Systematics 43: 429-448.

Sukenik, A., R. Eshkol, A. Livne, O. Hadas, M. Rom, D. Tchernov, A. Vardi \& K. Aaron, 2002. Inhibition of growth and photosynthesis of the dinoflagellate Peridinium gatunense by Microcystis sp. (Cyanobacteria): a novel allelopathic mechanism. Limnology and Oceanography 47: 16561663.

Tolotti, M., A. Boscaini \& N. Salmaso, 2010. Comparative analysis of phytoplankton patterns in two modified lakes with contrasting hydrological features. Aquatic Sciences Research Across Boundaries 72: 213-226.

Verdonschot, P., B. M. Spears, C. K. Feld, S. Brucet, H. KeizerVlek, A. Borja, M. Elliott, M. Kernan \& R. K. Johnson, 2013. A comparative review of recovery processes in rivers, lakes, estuarine and coastal waters. Hydrobiologia 704: 453-474.

Verspagen, J. M. H., J. Passarge, K. D. Jöhnk, P. M. Visser, L. Peperzak, P. Boers, H. J. Laanbroek \& J. Huisman, 2006. Water management strategies against toxic Microcystis blooms in the Dutch Delta. Ecological Applications 16: 313-327.

Vollenweider, R. A. \& J. Kerekes, 1982. Eutrophication of Waters: Monitoring, Assessment and Control. OECD Cooperative Programme on Monitoring of Inland Waters (Eutrophication Control). Environment Directorate, OECD, Paris: 154 pp.

Xu, F., S. E. Jørgensen, S. Tao \& B. Li, 1999. Modeling the effects of ecological engineering on ecosystem health of a shallow eutrophic Chinese lake (Lake Chao). Ecological Modelling 117: 239-260.

Zuur, A., E. N. Ieno, N. Walker, A. A. Saveliev \& G. M. Smith, 2009. Mixed Effects Models and Extensions in Ecology with R. Springer, New York. 